\title{
Effect of Some Mineral and Bio Fertilization Treatments on Yield and Yield Components of Bread Wheat Under Two Seeding Rates El-Metwally, E. A. ${ }^{1}$; M. E. R. Mekkei ${ }^{1}$; R. M. Abd El-Salam ${ }^{1}$ and H. M. Abo Shama ${ }^{2}$ ${ }^{1}$ Agronomy Dep., Fac. Agric., Cairo Univ., Egypt \\ ${ }^{2}$ Agronomist in Private Sector, Cairo, Egypt
}

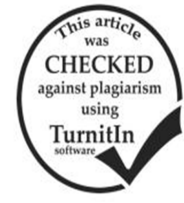

ABSTRACT

Two field experiments were carried out during 2013/2014 and 2014/2015 winter seasons at Agric. Res. Stat., Fac. Agric., Cairo Univ. Giza, Egypt to study the effect of two seeding rates i.e.50 and $65 \mathrm{~kg}$ seed/ faddan $\left(4200 \mathrm{~m}^{2}\right)$ and seven treatments of $\mathrm{N}, \mathrm{P}$ and $\mathrm{K}$ fertilizers with or without Cerealin inoculation on wheat growth, grain yield and its components. These seven treatments were T1 ( 0 - 0 - 0 NPK ), $\mathrm{T}_{2}(50-30$ - $24 \mathrm{NPK}), \mathrm{T}_{3}(65-37.5-36 \mathrm{NPK}), \mathrm{T}_{4}(80-45-48 \mathrm{NPK}), \mathrm{T}_{5}\left(\mathrm{~T}_{2}+\mathrm{Cerealin}\right)$, $\mathrm{T}_{6}\left(\mathrm{~T}_{3}+\right.$ Cerealin), and $\mathrm{T}_{7}\left(\mathrm{~T}_{4}+\right.$ Cerealin). A split plot design in randomized complete blocks arrangement with three replications was used. Seeding rates were randomly assigned for the main plots while, fertilizer treatments were randomly arranged for the sub plots. The obtained results showed that seeding rates had no significant effect on all yield attributes except, number of shoots $\mathrm{m}^{-2}$, number of grains spikes ${ }^{-1}$ in 2013/2014 season, number of shoots $\mathrm{m}^{-2}$, number of spikes $\mathrm{m}^{-2}$, straw yield /faddan and harvest index in 2013/2014 season. Mineral NPK fertilizers with bio-fertilizer (Cerealin) had significant effect on yield and its components except, spike length in both seasons. Grain, straw and biological yields and its attributes i.e. plant height, number of shoots $\mathrm{m}^{-2}$, number of spikes $\mathrm{m}^{-2}$, number of grains spike ${ }^{-1}$, grains weight spike ${ }^{-1}, 1000$-grain weight were significantly increased by adding bio-fertilizer compared to none adding in both seasons, respectively. Adding $75 \%$ of recommended dose of NPK mineral fertilizer combined with Cerealin inoculation resulted in significant increment in plant height, number of shoots $\mathrm{m}^{-2}$ number of spikes $\mathrm{m}^{-2}$, number of grains spike ${ }^{-1}$, grains weight spike ${ }^{-1}, 1000$-grain weight, grain, straw and biological yields as well as harvest index compared with other combination treatments. The interaction between seeding rate and fertilizer treatments was significant for all characters under study in both seasons. The highest grain yield (4.31 and 4.07 ton / faddan ) in both seasons, respectively was recorded by sowing $65 \mathrm{~kg}$ seed faddan ${ }^{-1}$ with adding $65 \mathrm{~kg} \mathrm{~N}+37.5 \mathrm{~kg} \mathrm{P}_{2} \mathrm{O}_{5}+36 \mathrm{~kg} \mathrm{~K} \mathrm{O}_{2} \mathrm{O}$ Cerealin inoculation compared with other tested treatments.

\section{INTRODUCTION}

Wheat (Triticum aestivum L.) is the main cereal crop in Egypt. It provides $37 \%$ of total calories for the people and $40 \%$ of the protein in Egyptian diet (Tawfik et al., 2016). It is also represent a major source of chaff for animal feeding. Wheat yield and end-use quality depend upon the environment, genotype, and their interaction (Zecvic et al., 2014). For achieving high yield and quality of wheat grain, it is important to apply all recommended cultural practices on adapted cultivars. Seeding rate is important for the wheat crop since it directly affects the number of ears per unit area. As a consequence other yield components such as the number of grains spike $^{-1}$ and individual grain weight (Ozturuk et al., 2006 and Valerio et al., 2013). Plant density is an important factor that influences the growth and yield formation in wheat (Hiltburnner et al., 2007). Previous studies have focused on identifying the optimal density for wheat cultivation, but the results vary based on the experimental conditions and tested parameters (Lioveras et al., 2004 and Luo et al., 2011). In wheat, the number of spikelets spike ${ }^{-1}$ changes under different planting densities (Dornbusch et al., 2011). The increase in grain number per spike contributes considerably to improve wheat grain yield potential. On the other hand, many investigators reported that different seeding rates had non-significant effect on wheat yield and its components among them (Kivi et al., 2010 and Piekarczyk, 2010).

Maintaining soil fertility and use of plant nutrients in sufficient and balanced amounts is one of the key factors in increasing crop yield (Diacono et al., 2013) and added that, nitrogen is the largest agricultural input used by wheat farmers. They generally over apply it because they want to ensure enough nitrogen for crop requirements increase. Increasing and extruding the role of bio-fertilizer can reduce the need for chemical fertilizers and decrease adverse environmental effects. They can play significant role in fixing atmospheric $\mathrm{N}$ and production of plant growth promoting substances (Attia and Abd El Salam, 2016). Many studies had addressed the advantageous effects of bacterial inoculation on plant physiology and growth of wheat (Singh et al., 2018, Namli et al., 2017 and Khalilzadeh et al., 2018). The inoculation with bio-fertilization had significant effect on plant height, grain weight spike ${ }^{-1}$, number of spikes $\mathrm{m}^{-2}$, number of grains spike ${ }^{-1}, 1000$ grain weight, grain, straw and biological yields in wheat plants (Namvar and Khandan, 2013 as well as Karimi and Marashi, 2017). Inoculation with Azospirillum ssp. resulting in an increase the yield of many cereals in the field by up to $30 \%$, but this increase is still associated with unpredictability and inconsistency which restricts its further development as a commercials inoculation on a large scale (Dobbelaere et al., 2002). Under Egyptian conditions, many investigations used Azospirillum brasilense under the commercials name Cerealin as a partial substitute for mineral fertilizers or for improving the resistance of some abiotic stresses in wheat and/or maize and they reported that, application of Cerealin combined with mineral fertilizers significantly increased most of growth, physiological character, NPK uptake as well as yield and yield components. On the other hand, they suggested we can save the mineral fertilizers about $20-30 \%$ by application of Cerealin along with mineral fertilizers (Ghallab and Salem, 2001; Abd El-Maksoud, 2002; Ibrahim et al., 2004; Shaban and Helmy, 2006; El-Garhi et al., 2007; Mahmoud, Abeer and Mohammed, Hanaa, 2008; Kabesh et al., 2009; ElGizawy, 2009 as well as Atta and Amein, 2016).

The objective of this study was to elucidate the effect of seeding rates and mineral NPK fertilizers, 
inoculation of Cerealin and its interactions on yields of wheat and its attributes.

\section{MATERIALS AND METHODS}

Two field experiments were carried out during 2013/2014 and 2014/2015 winter seasons at Agric. Res. Sta., at Giza, Fac. Agric., Cairo Univ. to study the effect of two seeding rates, three mineral NPK fertilizer rates with or without Cerealin inoculation and their interactions on wheat grain and straw yields and its attributes. Grains of Seds 13 wheat variety were supplied from Field Crop Institute, Agricultural Research Center (ARC). Two seeding rates, i.e. $50 \mathrm{~kg}$ seed faddan ${ }^{-1}\left(\sim 300\right.$ seed $\left.\mathrm{m}^{2}\right)$ and $65 \mathrm{~kg}$ seeds faddan ${ }^{-1}(\sim$ 390 seed $\mathrm{m}^{2}$ ) were drilled manually in rows spaced 20 $\mathrm{cm}$ apart on $21^{\text {th }}$ November, $24^{\text {th }}$ November during the two successive seasons of study, respectively. Azospirillum brasilense carried on vermiculite (Cerealin) as bacterial fixing nitrogen was obtained from bio-fertilizers unit, General Organization of Agriculture Equalization Fund, ARC at Giza, Egypt. Cerealin was added at a rate of $600 \mathrm{~g}$ faddan ${ }^{1}$. Soil inoculation with Cerealin was done at sowing time immediately prior to irrigation.
The tested seven fertilizer treatments $(\mathrm{kg}$ faddan $\left.^{-1}\right)$ could be summarized as follow: $\mathrm{T}_{1}(0-0-0$ NPK), $\mathrm{T}_{2}(50$ - 30 - $24 \mathrm{NPK}), \mathrm{T}_{3}(65$ - 37.5 - $36 \mathrm{NPK})$, $\mathrm{T}_{4}(80-45-48 \mathrm{NPK}), \mathrm{T}_{5}\left(\mathrm{~T}_{2}+\right.$ Cerealin $), \mathrm{T}_{6}\left(\mathrm{~T}_{3}+\right.$ Cerealin), and $\mathrm{T}_{7}\left(\mathrm{~T}_{4}+\right.$ Cerealin). Nitrogen, phosphorus and potassium were applied in the form of ammonium nitrate $(33.5 \% \mathrm{~N})$, calcium superphosphate $(15.5 \%$ $\left.\mathrm{P}_{2} \mathrm{O}_{5}\right)$ and potassium sulphate $\left(48.5 \% \mathrm{~K}_{2} \mathrm{O}\right)$, respectively. Whole of phosphorus and potassium were applied basally during soil preparation but Nitrogen, was divided into two equal doses and top dressed before the first and second irrigation at 21 and 42 days age, respectively. The preceding summer crop was corn in both seasons. All other agronomic practices were kept normal.

The experiment was laid out in a randomized complete block design with split plot arrangement replicated thrice. Seeding rates were assigned to the main plots, while the tested seven fertilizer treatments were randomly distributed in the sub plots. Each plot contained 15 rows $(20 \mathrm{~cm}$ apart, $3 \mathrm{~m}$ long). The experimental soil type was clay loam in both seasons. Mechanical and chemical properties of the experimental soil site during the two studied seasons are shown in Table 1.

Table 1. Mechanical and chemical properties of experimental site (30 depth) in 2013/2014 and 2014/2015 seasons

\begin{tabular}{lcc}
\hline \multirow{2}{*}{ Character } & \multicolumn{2}{c}{ Seasons } \\
\cline { 2 - 3 } Coarse sand (\%) & $\mathbf{2 0 1 3 / 2 0 1 4}$ & $\mathbf{2 0 1 4 / 2 0 1 5}$ \\
Fine sand (\%) & Mechanical analysis & 6.1 \\
Silt (\%) & 6.0 & 33 \\
Clay (\%) & 34 & 20 \\
Soil type & 20 & 41 \\
& 40 & Clay loam \\
Available N (kg/fed) & Clay loam & 25.3 \\
Available P (ppm) & Chemical analysis & 1988 \\
Available K (ppm) & 23.3 & 3200 \\
Organic matter (\%) & 1894 & 1.9 \\
PH & 3300 & 7.3 \\
EC (m/mohs/cm) & 1.1 & 0.8 \\
\hline
\end{tabular}

At harvest, six square meter were taken from the middle area of each plot to determine: plant height, number of shoots $\mathrm{m}^{-2}$, number of spikes $\mathrm{m}^{-2}$, spike length (Mean of 10 spikes), number of grains spike ${ }^{-}$ ${ }^{1}$ (Mean of 10 spikes), weight of spikes $\mathrm{m}^{-}$(Mean of 10 spikes), 1000-grain weight, grain yield faddan ${ }^{-1}$, straw yield faddan ${ }^{-1}$, biological yield faddan ${ }^{-1}$ and harvest index (\%). Data were subjected to analysis of variance according to Steel et al., (1997). Treatment means were compared based on least significant difference (LSD) at probability level of 0.05 . Finally, all statistical analysis was carried out using "MSTAT-C" program 1991.

\section{RESULTS AND DISCUSSION}

\section{Effect of seeding rates}

Results in Table 2 show the effect of seeding rates on wheat yields and its attributes during 2013/2014 and 2014/2015 seasons. Seeding rates had no significant effect on plant height, grains weight spike ${ }^{-1}$, 1000 grains weight, grain yield faddan ${ }^{-1}$ and biological yield faddan ${ }^{-1}$ in both seasons. Higher seeding rates $(65$ $\mathrm{kg}$ seeds faddan $^{-1}$ ) resulted in significant decrease in number of shoots $\mathrm{m}^{-2}$ in both seasons. However harvest index was significantly higher with increasing seeding rate from 50 to $65 \mathrm{~kg}$ seeds/faddan in 2014/2015 season only. Whereas, number of grains spike ${ }^{-1}$ significantly increased under the application of $65 \mathrm{~kg} /$ faddan seeding rate. Reducing interplant competition related with lower number of shoots $\mathrm{m}^{-2}$ generally results in concomitant increases in number of grains spike ${ }^{-1}$. In other contexts, there is a dynamic yield component compensation to balance among the yield components, which are competing for fixed resource during critical stages of development (Donaldson et al., 2001 and Gooding et 
al., 2002). Across a very wide range of seeds rates, the optimum seeding rate for wheat plant vary greatly from region to region according to climatic conditions, cropping system, weeds, soil, sowing time, winter or spring wheat and varieties. In this connection, Lioveras et al. (2004) mentioned that the recommended seeding rates in Belgium and Northern France is 200 seeds $\mathrm{m}^{2}$ but, In USA the recommended seeding rates ranged from 67 seeds $\mathrm{m}^{2}$ in dry land plains to 400 seeds $\mathrm{m}^{2}$ in the eastern regions of the North America, with 200 seeds $\mathrm{m}^{-2}$ at the most widely recommended rate in many areas of the USA. This basic rate can be increased by $50 \%$ under irrigated cropping system. According to our results there are no differences between both plant densities, so we can recommend by lower stand density as an ideal stand for wheat. Because the risk of lodging and disease infection related to higher plant density also, the lower density would represent a decrease in input of wheat production as saving in seed costs. Kivi et al. (2010), Piekarczyk (2010) and Shemi (2016) reported that seeding rates had on effect on wheat yield and its components.

Table 2. Effect of seeding rates on wheat yields and its attributes in 2013/2014 and 2014/2015 seasons.

\begin{tabular}{|c|c|c|c|c|c|c|}
\hline \multirow{2}{*}{ Characters } & \multicolumn{6}{|c|}{ Seeding rates (Kg/fed.) } \\
\hline & $\mathbf{5 0}$ & 65 & $\mathbf{L S D}_{0.05}$ & 50 & 65 & $\mathbf{L S D}_{0.05}$ \\
\hline & \multicolumn{3}{|c|}{$2013 / 2014$} & \multicolumn{3}{|c|}{$2014 / 2015$} \\
\hline Plant height $(\mathrm{cm})$ & 68.45 & 68.43 & ns & 67.44 & 67.31 & ns \\
\hline No. of shoots $\mathrm{m}^{-2}$ & 644.48 & 641.19 & 2.13 & 650.71 & 642.19 & 1.47 \\
\hline No. of spikes $\mathrm{m}^{-2}$ & 643.29 & 640.00 & ns & 649.76 & 640.76 & 1.11 \\
\hline Spike length $(\mathrm{cm})$ & 9.49 & 9.63 & ns & 9.59 & 9.52 & ns \\
\hline No. of grains spike ${ }^{-1}$ & 78.57 & 80.86 & 0.95 & 82.43 & 83.57 & ns \\
\hline Grains weight spike $^{-1}(\mathrm{~g})$ & 2.07 & 2.01 & $\mathrm{~ns}$ & 1.99 & 1.96 & ns \\
\hline 1000-grains weight $(\mathrm{g})$ & 40.23 & 41.49 & ns & 41.22 & 41.59 & $\mathrm{~ns}$ \\
\hline Grain yield faddan $^{-1}$ (ton) & 3.49 & 3.46 & ns & 3.42 & 3.64 & ns \\
\hline Straw yield faddan ${ }^{-1}$ (ton) & 3.84 & 3.75 & ns & 3.87 & 3.53 & 0.15 \\
\hline Biological yield faddan ${ }^{-1}$ (ton) & 7.33 & 7.21 & ns & 7.30 & 7.17 & ns \\
\hline Harvest index $(\%)$ & 47.62 & 47.99 & ns & 46.85 & 50.95 & 1.45 \\
\hline
\end{tabular}

\section{Effect of fertilizer treatments}

The effect of mineral NPK, Cerealin and its combination treatments on wheat yields and its attributes during 2013/2014 and 2014/2015 seasons are presented in Table 3. Generally, results showed that except spike length all characters under study were significantly affected by the tested fertilizer treatments in both seasons. In 2013/2014 season, data revealed that the highest values of plant height, grain weight spike ${ }^{-1}$ and yields (grain, straw and biological) faddan ${ }^{-1}$ were obtained by treatment T6 $\left(65 \mathrm{~kg} \mathrm{~N}+37.5 \mathrm{~kg} \mathrm{P}_{2} \mathrm{O}_{5}+36\right.$ $\mathrm{kg} \mathrm{K} \mathrm{K}_{2} \mathrm{O}+$ Cerealin). However, the highest number of shoots and spikes $\mathrm{m}^{-2}$, number of grains spike ${ }^{-1}$ and 1000-grain weight were achieved with $\mathrm{T}_{7}$.

In 2014/2015 season, the highest number of shoots and spikes per $\mathrm{m}^{2}$ were achieved with $\mathrm{T}_{7}(80 \mathrm{~kg}$ $\mathrm{N}+45 \mathrm{~kg} \mathrm{P}_{2} \mathrm{O}_{5}+48 \mathrm{~kg} \mathrm{~K} \mathrm{~K}_{2} \mathrm{O}+$ Cerealin). However, the highest values of plant height, number of grains, grains weight spike $^{-1}, 1000$-grain weight, yields faddan ${ }^{-1}$ of grains, straw and biological were produced with application of $\mathrm{T}_{6}\left(65 \mathrm{~kg} \mathrm{~N}+37.5 \mathrm{~kg} \mathrm{P}_{2} \mathrm{O}_{5}+36 \mathrm{~kg} \mathrm{~K}{ }_{2} \mathrm{O}\right.$ + Cerealin).

It can be concluded that bio-fertilizers in combination with NPK chemical fertilizer may increase availability and uptake of nutrient for wheat plants. The increment in yield and its components may be due to the increase in vegetative growth of plants and effects of bio-fertilizer on enhancing root growth and dry matter accumulation.

Ghallab and Salem, 2001and Ibrahim et al., 2004 as well as Atta and Amein, 2016 reported that the use of bio-fertilizers may have additional benefits such as nitrogen fixation and increasing the endogenous phytohormones i.e. Indole Acetic Acid (IAA),
Gibberellins $\left(\mathrm{GA}_{3}\right)$ and Cytokines like substances (CKs) which plays an important role in formation a big active root system and hence, increasing water and nutrients uptake, photosynthesis rate and translocation. Results of Attia and Abd El- Salam, 2016 emphasized that biofertilization is not a substitute but a partial supplement or the recommended NPK mineral fertilizers which could be ascribed partially to the increased mobility of fixed nutrients like $\mathrm{P}$ in the soil or fixing more $\mathrm{N}$ which reflected directly on most growth and yield characters of wheat in sandy soils. were results are in harmony with previous findings of Namvar and Khandan, 2013; Namli et al. 2017; Karimi and Marashi, 2017; Khalilzadeh et al., 2018 and Singh et al., 2018.

\section{Effect of the interaction}

Data presented in Tables 4 and 5 indicated that the interaction between seeding rates and fertilizer treatments were significant on all studied characters in 2013/2014 and 2014/2015 seasons.

Regarding plant height the interaction between seeding rates and fertilizer treatments had a significant effect on plant high in both seasons (Table 4). The longest wheat plants were obtained when plant of wheat received 65 - 37.5 - $36(\mathrm{NPK})+$ cerealin under seeding rate $50 \mathrm{~kg}_{\text {faddan }}{ }^{-1}$.

In terms of number of shoots $\mathrm{m}^{-2}$ and number of spikes $\mathrm{m}^{-2}$ a significant differences between seeding rates and fertilizer treatments were observed in both seasons (Table 4). The highest number of shoots $\mathrm{m}^{-2}$ and number of spikes $\mathrm{m}^{-2}$ were recorded with the application of $80-45-48$ (NPK) + cerealin under seeding rate 50 or $65 \mathrm{~kg} \mathrm{faddan}^{-1}$ without any significant differences between both seeding rates. 
Table 3. Effect of chemical-bio fertilizers treatments on wheat yields and its attributes in 2013/2014 and 2014/2015 seasons.

\begin{tabular}{|c|c|c|c|c|c|c|c|c|}
\hline \multirow{2}{*}{ Characters } & \multicolumn{7}{|c|}{ Fertilizer treatments* } & \multirow{2}{*}{$\mathbf{L S D}_{0.05}$} \\
\hline & $T_{1}$ & $T_{2}$ & $\mathbf{T}_{3}$ & $\mathbf{T}_{4}$ & $\mathbf{T}_{5}$ & $\mathbf{T}_{6}$ & $\mathbf{T}_{7}$ & \\
\hline & \multicolumn{3}{|c|}{ 2013/2014 Season } & & & & & \\
\hline Plant height $(\mathrm{cm})$ & 66 & 67 & 68 & 69 & 69 & 71 & 69 & 1.10 \\
\hline No. of shoots $\mathrm{m}^{-2}$ & 611 & 615 & 620 & 629 & 656 & 680 & 689 & 3.99 \\
\hline No. of spikes m ${ }^{-2}$ & 609 & 614 & 619 & 629 & 654 & 678 & 688 & 3.35 \\
\hline Spike length $(\mathrm{cm})$ & 9.25 & 9.52 & 9.45 & 9.70 & 9.88 & 9.70 & 9.42 & ns \\
\hline No. of grains spike ${ }^{-1}$ & 71.8 & 74.7 & 74.8 & 78.0 & 81.5 & 88.5 & 88.7 & 1.79 \\
\hline Grains weight spike $^{-1}(\mathrm{~g})$ & 1.67 & 1.82 & 2.02 & 2.07 & 2.15 & 2.30 & 2.27 & 0.16 \\
\hline 1000 -grains weight $(\mathrm{g})$ & 37.3 & 39.4 & 39.1 & 40.9 & 42.6 & 42.9 & 43.7 & 1.05 \\
\hline Grain yield faddan ${ }^{-1}$ (ton) & 2.76 & 3.04 & 3.35 & 3.31 & 3.84 & 4.16 & 3.89 & 0.19 \\
\hline Straw yield faddan ${ }^{-1}$ (ton) & 3.00 & 3.62 & 3.74 & 4.40 & 4.04 & 3.98 & 3.80 & 0.35 \\
\hline Biological yield faddan ${ }^{-1}$ (ton) & 5.76 & 6.66 & 7.08 & 7.71 & 7.88 & 8.14 & 7.69 & 0.26 \\
\hline Harvest index $(\%)$ & 47.9 & 45.7 & 47.4 & 42.9 & 48.7 & 51.3 & 50.7 & 3.34 \\
\hline \multirow[b]{2}{*}{ Plant height $(\mathrm{cm})$} & \multicolumn{3}{|c|}{ 2014/2015 Season } & & & & & \\
\hline & 65 & 65 & 67 & 67 & 68 & 71 & 71 & 1.42 \\
\hline No. of shoots $\mathrm{m}^{-2}$ & 614 & 621 & 625 & 633 & 663 & 682 & 688 & 2.75 \\
\hline No. of spikes $\mathrm{m}^{-2}$ & 612 & 620 & 624 & 633 & 661 & 680 & 687 & 2.08 \\
\hline Spike length $(\mathrm{cm})$ & 9.35 & 9.37 & 9.67 & 9.70 & 9.62 & 9.70 & 9.48 & $\mathrm{~ns}$ \\
\hline No. of grains spike ${ }^{-1}$ & 74.0 & 76.5 & 80.0 & 86.9 & 86.5 & 89.0 & 88.2 & 2.14 \\
\hline Grains weight spike $^{-1}(\mathrm{~g})$ & 1.68 & 1.82 & 1.90 & 1.92 & 2.03 & 2.25 & 2.23 & 0.14 \\
\hline 1000 -grains weight $(\mathrm{g})$ & 38.9 & 40.1 & 40.9 & 41.1 & 42.8 & 44.3 & 41.8 & 1.73 \\
\hline Grain yield faddan ${ }^{-1}$ (ton) & 2.79 & 3.11 & 3.39 & 3.82 & 3.67 & 4.01 & 3.93 & 0.18 \\
\hline Straw yield faddan ${ }^{-1}$ (ton) & 2.71 & 3.33 & 3.71 & 3.95 & 3.88 & 4.24 & 4.12 & 0.28 \\
\hline Biological yield faddan ${ }^{-1}$ (ton) & 5.49 & 6.44 & 7.10 & 7.77 & 7.55 & 8.25 & 8.04 & 0.27 \\
\hline Harvest index $(\%)$ & 50.8 & 48.6 & 47.9 & 49.2 & 48.7 & 48.7 & 48.9 & 2.71 \\
\hline
\end{tabular}

* $T_{1}: 0$ - 0 - 0 (NPK), $T_{2}: 50$ - 30 - 24 (NPK), T3: 65 - 37.5 - 36 (NPK), $T_{4}: 80$ - 45 - 48 (NPK), T5: $T_{2}+$ Cerealin, $T_{6}: T_{3}+$ Cerealin, and $\mathbf{T}_{7}: \mathbf{T}_{4}+$ Cerealin.

With regarded to spike length, seeding rates and fertilizer treatments interaction had a significant effect on spike length in the first and second seasons (Table 4). The tallest spike of wheat was produced with the application of $80-45-48$ (NPK) under seeding rate 50 $\mathrm{kg} \mathrm{faddan}^{-1}$ and $50-30-24$ (NPK) + Cerealin under seeding rate $65 \mathrm{~kg}$ faddan $^{-1}$ in the first and second seasons, respectively.

Table 4. Effect of interaction between seeding rates and chemical-bio fertilizer combination treatments on some agronomic characters of wheat in 2013/2014 and 2014/2015 seasons.

\begin{tabular}{|c|c|c|c|c|c|c|c|c|c|c|c|c|c|}
\hline \multirow{2}{*}{$\begin{array}{l}\text { Fertilizer* } \\
\text { treatments } \\
\text { kg faddan }^{-1}\end{array}$} & \multirow{2}{*}{$\begin{array}{c}\text { Seed } \\
\text { Rates } \\
\text { (Kg } \\
\text { /fad.) }\end{array}$} & \multicolumn{2}{|c|}{$\begin{array}{l}\text { Plant height } \\
\text { (cm) }\end{array}$} & \multicolumn{2}{|c|}{$\begin{array}{c}\text { No. of shoots } \\
\mathrm{m}^{-2}\end{array}$} & \multicolumn{2}{|c|}{$\begin{array}{l}\text { No. of spikes } \\
\mathrm{m}^{-2}\end{array}$} & \multicolumn{2}{|c|}{$\begin{array}{c}\text { Spike length } \\
\text { (cm) }\end{array}$} & \multicolumn{2}{|c|}{$\begin{array}{c}\text { No. of grains } \\
\text { spike }^{-1}\end{array}$} & \multicolumn{2}{|c|}{$\begin{array}{c}\text { Grains weight } \\
\text { spike }^{-1}(\mathrm{~g})\end{array}$} \\
\hline & & $\begin{array}{c}1^{\text {st }} \\
\text { Season }\end{array}$ & $\begin{array}{c}2^{\text {nd }} \\
\text { Season }\end{array}$ & $\begin{array}{c}1^{\text {st }} \\
\text { Season }\end{array}$ & $\begin{array}{c}2^{\text {nd }} \\
\text { Season }\end{array}$ & $\begin{array}{c}1^{\text {st }} \\
\text { Season }\end{array}$ & $\begin{array}{c}2^{\text {nd }} \\
\text { Season }\end{array}$ & $\begin{array}{c}1^{\text {st }} \\
\text { Season }\end{array}$ & $2^{\text {nd }}$ Season & $\begin{array}{c}1^{\text {st }} \\
\text { Season }\end{array}$ & $\begin{array}{c}2^{\text {nd }} \\
\text { Season }\end{array}$ & $\begin{array}{c}1^{\text {st }} \\
\text { Season }\end{array}$ & $\begin{array}{c}2^{\text {nd }} \\
\text { Season }\end{array}$ \\
\hline \multirow[t]{2}{*}{$\overline{\mathrm{T}_{1}}$} & 50 & $65.8 \mathrm{f}$ & $65.7 \mathrm{c}$ & $612.3 \mathrm{gh}$ & & $611.0 \mathrm{gh}$ & $615.3 \mathrm{i}$ & $9.23 \mathrm{~b}$ & $8.97 d$ & $71.0 \mathrm{~g}$ & $72.7 \mathrm{~g}$ & $1.70 \mathrm{~d}$ & $1.77 \mathrm{ef}$ \\
\hline & 65 & $67.0 \mathrm{ef}$ & $64.8 \mathrm{c}$ & $608.7 \mathrm{~h}$ & $611.7 \mathrm{i}$ & $607.0 \mathrm{~h}$ & $610.0 \mathrm{j}$ & $9.27 \mathrm{~b}$ & $9.73 \mathrm{abc}$ & $72.7 \mathrm{fg}$ & $75.3 \mathrm{efg}$ & $1.63 \mathrm{~d}$ & $1.60 \mathrm{f}$ \\
\hline \multirow[t]{2}{*}{$\mathrm{T}_{2}$} & 50 & & & & & & & $9.60 \mathrm{ab}$ & & $72.3 \mathrm{fg}$ & 74.7ef & & $1.93 \mathrm{de}$ \\
\hline & & & & & & & & & & $7.0 \mathrm{~cd}$ & & $1.67 \mathrm{~d}$ & $1.70 \mathrm{f}$ \\
\hline \multirow[t]{2}{*}{$\mathrm{T}_{3}$} & 50 & $8.2 \mathrm{cde}$ & $66.3 \mathrm{c}$ & $20.3 \mathrm{f}$ & & $619.3 \mathrm{f}$ & $623.7 \mathrm{~h}$ & $9.47 \mathrm{ab}$ & & 74.3ef & 77.0ef & $2.00 \mathrm{bc}$ & $1.90 \mathrm{de}$ \\
\hline & 65 & $68.1 \mathrm{cde}$ & $66.6 \mathrm{c}$ & $20.3 f$ & & $619.3 f$ & $624.0 \mathrm{~h}$ & $9.43 \mathrm{ab}$ & 9.4 & $75.3 \mathrm{de}$ & $83.0 \mathrm{~d}$ & $2.03 \mathrm{bc}$ & $1.90 \mathrm{de}$ \\
\hline \multirow[t]{2}{*}{$\mathrm{T}_{4}$} & 50 & $8.8 \mathrm{~cd}$ & $66.2 \mathrm{c}$ & & & & $.3 \mathrm{f}$ & $9.60 \mathrm{ab}$ & & $77.3 \mathrm{~cd}$ & $88.3 \mathrm{abc}$ & $2.07 \mathrm{bc}$ & $1.93 \mathrm{de}$ \\
\hline & & de & & & & & & & & & $85.3 \mathrm{~cd}$ & $2.07 \mathrm{bc}$ & $1.90 \mathrm{de}$ \\
\hline \multirow[t]{2}{*}{$\mathrm{T}_{5}$} & 50 & $69.0 \mathrm{c}$ & $66.6 \mathrm{c}$ & $665.7 \mathrm{c}$ & & 664. & $672.7 \mathrm{~d}$ & $9.60 \mathrm{ab}$ & & $78.7 \mathrm{c}$ & $86.7 \mathrm{abc}$ & $2.13 \mathrm{abc}$ & $2.03 \mathrm{~cd}$ \\
\hline & 5 & 68.1 cde & $68.8 \mathrm{~b}$ & & & $643.7 \mathrm{~d}$ & $50.0 \mathrm{e}$ & $10.17 \mathrm{a}$ & & $84.3 b$ & $86.3 \mathrm{bc}$ & $2.17 \mathrm{abc}$ & $2.03 \mathrm{~cd}$ \\
\hline \multirow{2}{*}{$\mathrm{T}_{6}$} & & & & & & $677.7 \mathrm{~b}$ & & $9.73 \mathrm{ab}$ & & & $88.3 \mathrm{abc}$ & $2.30 \mathrm{a}$ & $2.23 \mathrm{ab}$ \\
\hline & & $70.7 \mathrm{ab}$ & $70.6 \mathrm{ab}$ & & & & & $9.67 \mathrm{ab}$ & & & $89.7 \mathrm{a}$ & $2.30 \mathrm{a}$ & $2.27 \mathrm{ab}$ \\
\hline \multirow[t]{2}{*}{$\mathrm{T}_{7}$} & 50 & $69.0 \mathrm{c}$ & $70.8 \mathrm{ab}$ & $689.0 \mathrm{a}$ & & $687.3 \mathrm{a}$ & $692.0 \mathrm{a}$ & $9.20 \mathrm{~b}$ & & $88.3 \mathrm{a}$ & $89.3 \mathrm{ab}$ & $2.33 \mathrm{a}$ & $2.13 \mathrm{bc}$ \\
\hline & 65 & $69.6 \mathrm{bc}$ & $70.2 \mathrm{ab}$ & $688.7 \mathrm{a}$ & & $687.7 \mathrm{a}$ & $682.0 \mathrm{c}$ & $9.63 \mathrm{ab}$ & 9.43 & $89.0 \mathrm{a}$ & $87.0 \mathrm{abc}$ & $2.20 \mathrm{ab}$ & $2.33 \mathrm{a}$ \\
\hline LSD 0.05 & & 1.6 & 2.0 & 5.7 & 3.9 & 4.7 & 3.0 & 0.90 & 0.75 & 2.5 & 3.0 & 0.23 & 0.19 \\
\hline
\end{tabular}

${ }^{*} T_{1}: 0$ - 0 - 0 (NPK), $T_{2}: 50$ - 30 - 24 (NPK), $T_{3}: 65$ - 37.5 - 36 (NPK), $T_{4}: 80$ - 45 - 48 (NPK), $T_{5}: T_{2}+$ Cerealin, $T_{6}: T_{3}+$ Cerealin, and $\mathrm{T}_{7}: \mathrm{T}_{4}+$ Cerealin.

With respect to number of grains spike ${ }^{-1}$, there was a significant effect between seeding rates and fertilizer treatments interaction (Table 4). The highest number of grains spike ${ }^{-1}$ resulted from the application of 65 - 37.5 - 36 (NPK) along with Cerealin without a significant difference between the highest and the lowest seeding rate.

For grains weight spike $^{-1}$, the interaction between seeding rates and fertilizer treatments had a significant effect on grains weight spike $^{-1}$ in both seasons (Table 4). The highest value of grains weights spike $^{-1}$ recorded when the plant of wheat received 80 -
45 - 48 (NPK) along with Cerealin under seeding rate 50 and $65 \mathrm{~kg} /$ faddan in 2013/2014 and 2014/2015, respectively.

Concerning 1000-grain weight, was significantly affected by the interaction between seeding rates and fertilizer treatments in both seasons (Table 5). The heaviest 1000 -grains weigh were produced with $\mathrm{T}_{6}$ and $\mathrm{T}_{7}$ in $2013 / 2014$ and $2014 / 2015$, respectively without significant difference between two treatments in both seasons.

Regarding grain yield faddan $^{-1}$, a significant difference between seeding rate and fertilization 
treatments were observed in both seasons (Table 5). The highest value of grain yield faddan ${ }^{-1}$ was achieved when the plant of wheat received 65 - 37.5 - 36 (NPK) along with Cerealin under $65 \mathrm{~kg} /$ faddan seeding rate.

With respect to straw yield faddan ${ }^{-1}$ and biological yield faddan ${ }^{-1}$, there was a significant effect between seeding rate and fertilizer treatments in both seasons (Table 5). The highest yields of straw and biological yield faddan $^{-1}$ produced under fertilizer treatment $65-37.5$ - $36(\mathrm{NPK})$ with $50 \mathrm{~kg}$ faddan $^{-1}$ seeding rate.

With regarded to harvest index, the interaction between seeding rates and fertilizer treatments had a significant effect on harvest index in both seasons (Table 5). The highest percentage of harvest index recorded with 65 - 37.5 - 36 (NPK) along with Cerealin in 2013/2014 season and the same treatment alone in $2014 / 2015$ season under $65 \mathrm{~kg}$ faddan $^{-1}$ seeding rate in both seasons.

Table 5. Effect of interaction between seeding rates and chemical - bio fertilizer combination treatments on some agronomic characters of wheat in 2014/2014 and 2014/2015 seasons

\begin{tabular}{|c|c|c|c|c|c|c|c|c|c|c|c|}
\hline \multirow{2}{*}{$\begin{array}{l}\text { Fertilizer } \\
\text { Treatments* }\end{array}$} & \multirow{2}{*}{$\begin{array}{c}\text { Seed } \\
\text { Rates } \\
\text { (Kg } \\
\text { /fad.) }\end{array}$} & \multicolumn{2}{|c|}{$\begin{array}{l}\text { 1000-grains weight } \\
\text { (g) }\end{array}$} & \multicolumn{2}{|c|}{$\begin{array}{l}\text { Grain yield fad. }^{-1} \\
\text { (ton) }\end{array}$} & \multicolumn{2}{|c|}{ Straw yield fad..$^{-1}$ (ton) } & \multicolumn{2}{|c|}{$\begin{array}{l}\text { Biological yield fad } \\
\text { (ton) }\end{array}$} & \multicolumn{2}{|c|}{$\begin{array}{c}\text { Harvest index } \\
(\%)\end{array}$} \\
\hline & & $\begin{array}{c}1^{\text {st }} \\
\text { Season }\end{array}$ & $\begin{array}{c}2^{\text {nd }} \\
\text { Season }\end{array}$ & $\begin{array}{c}1^{\text {st }} \\
\text { Season }\end{array}$ & $\begin{array}{c}2^{\text {nd }} \\
\text { Season }\end{array}$ & $\begin{array}{c}1^{\text {st }} \\
\text { Season } \\
\end{array}$ & $\begin{array}{c}2^{\text {nd }} \\
\text { Season } \\
\end{array}$ & $\begin{array}{c}1^{\text {st }} \\
\text { Season } \\
\end{array}$ & $\begin{array}{c}2^{\text {nd }} \\
\text { Season }\end{array}$ & $\begin{array}{c}1^{\text {st }} \\
\text { Season } \\
\end{array}$ & $2^{\text {nd }}$ Season \\
\hline \multirow{2}{*}{$\mathrm{T}_{1}$} & 50 & $37.17 \mathrm{i}$ & $37.80 \mathrm{e}$ & $2.76 \mathrm{e}$ & $2.63 \mathrm{f}$ & $3.07 \mathrm{fg}$ & $2.73 d$ & $5.83 \mathrm{f}$ & $5.36 \mathrm{~g}$ & $47.30 \mathrm{bcd}$ & $49.17 \mathrm{~cd}$ \\
\hline & 65 & 37.33hi & $39.93 \mathrm{de}$ & $2.75 \mathrm{e}$ & $2.94 \mathrm{e}$ & $2.94 \mathrm{~g}$ & $2.68 \mathrm{~d}$ & $5.69 f$ & $5.62 \mathrm{~g}$ & $48.37 \mathrm{bcd}$ & $52.37 \mathrm{abc}$ \\
\hline \multirow[t]{2}{*}{$\mathrm{T}_{2}$} & 50 & $38.43 \mathrm{ghi}$ & $67 \mathrm{de}$ & $3.03 \mathrm{~d}$ & $2.96 \mathrm{e}$ & $3.51 \mathrm{ef}$ & $3.78 \mathrm{~b}$ & $6.54 \mathrm{e}$ & $6.74 \mathrm{e}$ & $46.43 \mathrm{~cd}$ & $93 \mathrm{ef}$ \\
\hline & 65 & $40.43 \mathrm{de}$ & $40.50 \mathrm{~cd}$ & $3.04 \mathrm{~d}$ & $3.27 \mathrm{~d}$ & $3.73 \mathrm{cde}$ & $2.87 \mathrm{~cd}$ & $6.77 \mathrm{e}$ & $6.14 f$ & $44.97 \mathrm{~d}$ & $53.17 \mathrm{ab}$ \\
\hline \multirow[t]{2}{*}{$\mathrm{T}_{3}$} & 50 & $38.80 \mathrm{fgh}$ & $40.37 \mathrm{~cd}$ & $3.35 \mathrm{c}$ & $3.05 \mathrm{de}$ & $4.03 \mathrm{bcd}$ & $4.26 \mathrm{a}$ & $7.39 \mathrm{~d}$ & $7.31 \mathrm{~d}$ & $45.40 \mathrm{~cd}$ & $41.73 f$ \\
\hline & 65 & $39.47 \mathrm{efg}$ & $41.43 \mathrm{bcd}$ & $3.34 \mathrm{c}$ & $3.74 b c$ & $3.44 \mathrm{ef}$ & $3.16 \mathrm{c}$ & $6.78 \mathrm{e}$ & $6.90 \mathrm{e}$ & $49.33 \mathrm{bcd}$ & $54.20 \mathrm{a}$ \\
\hline \multirow[t]{2}{*}{$\mathrm{T}_{4}$} & 50 & $40.03 \mathrm{ef}$ & $41.30 \mathrm{bcd}$ & $3.56 \mathrm{c}$ & $3.75 b c$ & $4.10 \mathrm{bcd}$ & $3.97 \mathrm{ab}$ & $7.66 \mathrm{bcd}$ & $7.73 \mathrm{c}$ & $46.50 \mathrm{~cd}$ & $48.57 \mathrm{~cd}$ \\
\hline & 65 & 41.7 & 40. & $3.06 \mathrm{~d}$ & $3.89 \mathrm{ab}$ & & $3.92 \mathrm{ab}$ & & $7.81 \mathrm{c}$ & $39.47 \mathrm{e}$ & 3 bcd \\
\hline \multirow[t]{2}{*}{$\mathrm{T}_{5}$} & 50 & $42.23 c$ & $42.97 \mathrm{ab}$ & $3.84 \mathrm{~b}$ & $3.72 b c$ & $4.18 b c$ & $3.79 \mathrm{~b}$ & $8.02 \mathrm{ab}$ & $7.50 \mathrm{~cd}$ & $48.00 \mathrm{bcd}$ & $49.67 \mathrm{bcd}$ \\
\hline & 65 & $43.00 \mathrm{bc}$ & $42.67 \mathrm{abc}$ & $3.84 b$ & $3.61 \mathrm{c}$ & $3.89 \mathrm{bcde}$ & $3.98 \mathrm{ab}$ & $7.74 \mathrm{bcd}$ & $7.59 \mathrm{~cd}$ & 49.70abc & $47.63 \mathrm{de}$ \\
\hline \multirow[t]{2}{*}{$\mathrm{T}_{6}$} & 50 & $42.20 \mathrm{c}$ & $44.03 \mathrm{a}$ & $4.02 \mathrm{~b}$ & $3.96 \mathrm{ab}$ & $4.34 \mathrm{ab}$ & $4.28 \mathrm{a}$ & $8.36 \mathrm{a}$ & $8.25 \mathrm{ab}$ & $48.23 \mathrm{bcd}$ & $48.03 \mathrm{~d}$ \\
\hline & 65 & $43.73 \mathrm{ab}$ & & $4.31 \mathrm{a}$ & $4.07 \mathrm{a}$ & $3.62 \mathrm{de}$ & $4.19 \mathrm{a}$ & $7.92 b$ & $8.26 a$ & $54.30 \mathrm{a}$ & $49.30 \mathrm{bcd}$ \\
\hline \multirow[t]{2}{*}{$\mathrm{T}_{7}$} & 50 & $42.77 b c$ & $42.43 \mathrm{abc}$ & $3.88 \mathrm{~b}$ & $3.91 \mathrm{ab}$ & $3.67 \mathrm{de}$ & $4.31 \mathrm{a}$ & $7.55 \mathrm{~cd}$ & $8.21 \mathrm{ab}$ & $51.50 \mathrm{ab}$ & $47.57 \mathrm{de}$ \\
\hline & 65 & $44.70 \mathrm{a}$ & $41.17 \mathrm{bcd}$ & $3.90 \mathrm{~b}$ & $3.94 \mathrm{ab}$ & $3.93 \mathrm{bcde}$ & $3.93 \mathrm{ab}$ & $7.83 \mathrm{bc}$ & $7.87 \mathrm{bc}$ & $49.80 \mathrm{abc}$ & $50.13 \mathrm{bcd}$ \\
\hline LSD 0.05 & & 1.49 & 2.45 & 0.27 & 0.25 & 0.50 & 0.40 & 0.36 & 0.38 & 4.72 & 3.84 \\
\hline
\end{tabular}

${ }^{*} T_{1}: 0$ - 0 - 0 (NPK), $T_{2}: 50$ - 30 - 24 (NPK), $T_{3}: 65-37.5$ - 36 (NPK), $T_{4}: 80$ - 45 - 48 (NPK), $T_{5}: T_{2}+$ Cerealin, $T_{6}: T_{3}+$ Cerealin, and $T_{7}:$ $\mathrm{T}_{4}+$ Cerealin.

\section{REFERENCES}

Abd El-Maksoud, M. F. (2002). Response of some wheat cultivars to biofertilizer and nitrogen fertilizer levels. Zagazig J. Agric. Res., 29(3): 891-905.

Atta, M. M. M. and Amein, M. M. M. (2016). Response of six maize hybrids and populations to bacterial fixing nitrogen as biofertilizer. World J. Agric. Sci., 12(1): 15-24.

Attia, M. A. and Abd El Salam, A. A. (2016). Effect of mineral, organic and bio-fertilizer on yield and yield components of bread wheat at Siwa Oasis. Alex. J. Agric. Sci., 61(3): 211-219.

Diacono, M.; Rubino, P. and Montemurro, F. (2013). Precision nitrogen management in wheat a review. Agron. Sustain. Dev., 3(1): 219-221.

Dobbelaere, S.; Croonenborghs, A.; Thys, A.; Ptacek, D.; Okon,Y. and Vanderleyden, J. (2002). Effect of inoculation with wild type Azospirillum brasilense and A. irakense strains on development and nitrogen uptake of spring wheat and grain maize. Bio. Fertil. Soil, 36: 284-297.

Donaldson, E.; Schillinger, W. F. and Dofing, S. M. (2001). Straw production and grain yield relationships in winter wheat. Crop Sci., 41:100106.

Dornbusch, T.; Baccar, R.; Watt, J.; Bertheloot, J. and Fournier, C. (2011). Plasticity of winter wheat modulated by sowing date, plant population density and nitrogen fertilization: dimensions and size of leaf blades, sheaths and internodes in relation to their position on a stem. Field Crops Res., 121(1):116-124.
El-Garhi, I. A.; Mettwally, A. S.; Atia, N. A. and Sara Fouda, E. E. (2007). Effect of inoculating Nfixing bacteria (A Cerialin) on wheat (Triticum aestivum) growth and nutrient contents. Zagazig J. Agric. Res., 34(2): 249-273.

El-Gizawy, N. Kh. B.(2009). Effect of planting date and fertilizer application on yield of wheat under no till system. World J. Agric. Sci., 5(6): 777-783.

Ghallab, A. M. and Salem, S. M. (2001). Effect of some biofertilizer treatments on growth, chemical composition and productivity of wheat plants grown under different levels of NPK fertilization. Annals Agric. Sci., Ain shams, Cairo, 46(2): 485-509.

Gooding, M. J.; Pinyosinwat, A. and Ellis, R. H. (2002). Responses of wheat grain yield and quality to seed rate. J. Agric. Sci., 138:317-331.

Hiltburnner, J.; Streit, B. and Liedgens, M. (2007). Are seeding densities an opportunity to increase grain yield of winter wheat in a living mulch of white clover? Field Crops Res., 102(3):163-171.

Ibrahim, E. M.; Bassal, S. A. A. and Bader, M. M. A. (2004). Effect of tillage systems, bio fertilization and spraying urea on wheat productivity. Zagazig J. Agric. Res., 31(2): 491-507.

Kabesh, M. O.; El-Kramany, M. F.; Sary, G. A.; ElNaggar, H. M. and Bakhoum, Gehan, Sh. H. (2009). Effect of sowing methods and some bioorganic fertilization treatments on yield and yield components of wheat. Res. J. Agric. Bio. Sci., 5(1): 97-102. 
Karimi, M. and Marashi, S.K. (2017). Effect of combined application of chemical and biological phosphorus and nitrogen fertilizers on yield and yield components of wheat. J. Agric. Res., 8 (5):41-52.

Khalilzadeh, R.; Sharifi, R.S. and Jalilian, J. (2018). Growth, physiological status, and yield of saltstressed wheat (Triticum aestivum L.) plants affected by biofertilizer and cycocel applications. Arid Land Res. Manag., 32(1): 71-90.

Kivi, M. P.; Mahmoodabad, R. Z.; Somarin; S. J. and Khayatnezhad, M. (2010). Interaction effect of plant densities and nitrogen fertilizer on durum wheat (CV. Seymareh) growth. AmericanEurasian J. Agric. Environ. Sci., 9(3):263-268.

LIoveras, J.; Manent, J.; Viudas, J.; Lopez, A. and Santiveri, P. (2004). Seeding rate influence on yield and yield components of irrigated winter wheat in a Mediterranean climate. Agron. J., 96(5):1258-1265.

Luo, L.P.; Yu, Z.W.; Wang, D.; Zhang, Y.L. and Shi, Y. (2011). Effects of plant density and soil moisture on photosynthetic characteristics of flag leaf and accumulation and distribution of dry matter in wheat. Acta. Agron. Sin., 37(6):1049-1059.

Mahmoud, Abeer, A. and Mohamed, Hanaa, F.Y.(2008). Impact of Biofertilizers Application on Improving Wheat (Triticum aestivum L.) Resistance to Salinity. Res. J. Agric. Bio. Sci., 4(5): 520-528.

MSTAT-C (1991). A Software Program for Design, Management, and Analysis of Agronomic Research Experiments. Michigan State University, East Lansing MI.

Namli, A.; Mahmood, A.; Sevili, B. and Ozkir, E. (2017). Effect of phosphorus solubilizing bacteria on some soil properties, wheat yield and nutrient contents. Eurasian J. Soil Sci., 6(3):249258.

Namvar, A. and Khandan, T. (2013). Response of wheat to mineral nitrogen fertilizer and biofertilizer (Azotobacter sp. and Azospirillum sp.) inoculation under different levels of weed interference. Ecological, 59(2):85-94.

Ozturuk, A.; Caglar, O. and Bulut, S. (2006). Growth and yield response of facultative wheat to winter sowing, freezing sowing and spring sowing at different seeding rates. J. Agron. Crop Sci., 192:10-16.

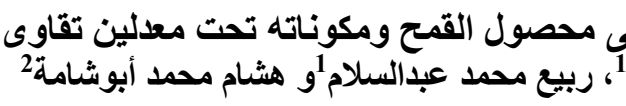

Piekarczyk, M. (2010). Effect of fertilization dose, plant protection input, and seeding density on the yield and grain technological quality of winter wheat grown in short-time monoculture on light soil. Act. Sci. Pol. Agric., 9(2):15-23.

Shaban, Kh. A. and Helmy, A. M. (2006). Response of wheat to mineral and bio $\mathrm{N}$ - fertilization under saline conditions. Zagazig J. Agric. Res., 33(6): 1189-1205.

Shemi, R. G. M. I. (2016). Productivity and nitrogen use efficiency of some wheat varieties under different seeding rates and nitrogen fertilizer levels, M.Sc. Thesis, Fac. Agric., Cairo University.

Singh, V.; Rana, N. S.; Dhyani, B.P.; Kumar, R.; Naresh, R. K. and Kumar, A. (2018). Influences of organic and inorganic fertilizers on productivity and soil fertility of wheat (Triticum aestivum L.) in Typic Ustochrept soil of Uttar Pradesh. J. Pharmacognosy and Phytochemistry, $7(1): 260-265$.

Steel, R.G.D.; Torrie, J. H. and Dicky, D.A. (1997). Principles and procedures of statistics: a biometrical approach. $3^{\text {rd }}$ Ed. McGraw Hill, Inc. Book Co. N.Y, (U.S.A.), pp: 352-358.

Tawfik, M. M.; Abd El-Salam, M. S.; Abd El- Lateef, E. M. and Mirvat, E. Gobarah (2016). Integrated effect of some bio and chemical fertilization treatments on wheat growth and yield under sandy soil conditions. Inter. J. Chem. Tech. Res., 9(7): 281-291.

Valerio, I. P.; De Carvalho, F.I. F.; Benin, G.; Da Silveria, G.; Da Silva, J. A. G.; Nornberg, R.; Hagemann, T.; Luche, H.D.S. and De Olveria, A. C. (2013). Seeding density in wheat: the more, the merrier? Scientia Agricola, 70(3):176-184.

Zecvic, V.; Boskovic, J.; Knezevic, D. and Micanovic, D. (2014). Effect of seeding rate on grain quality of winter wheat. Chliean J. Agric. Res., 74(1):2328.

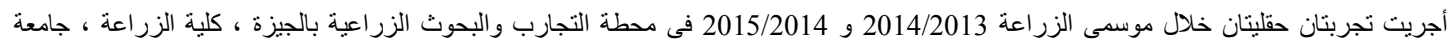

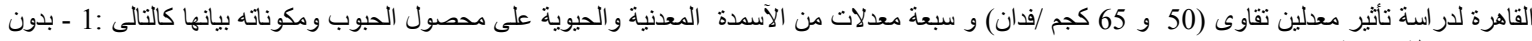

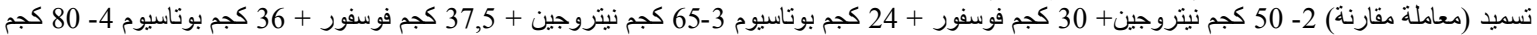

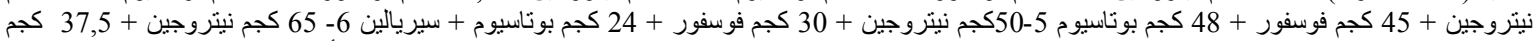

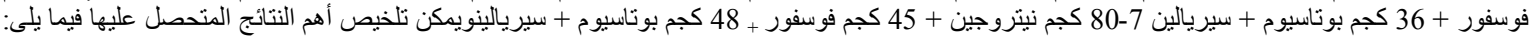

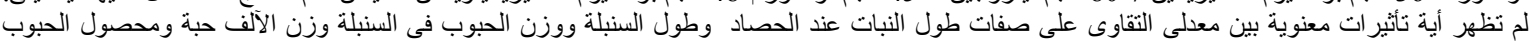

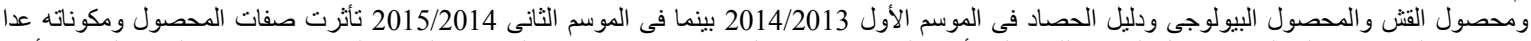

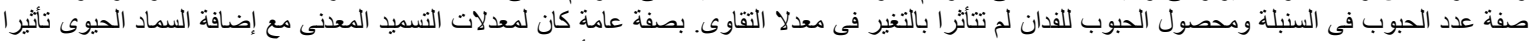

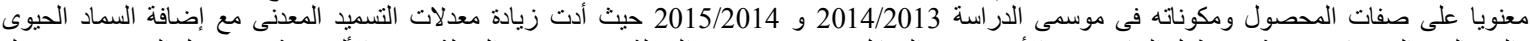

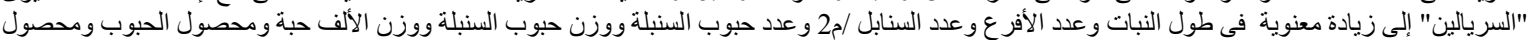

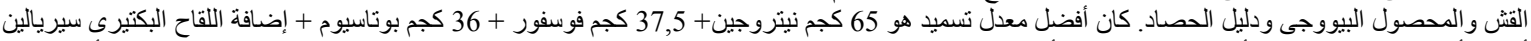

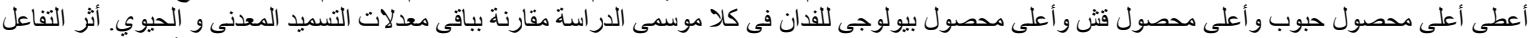

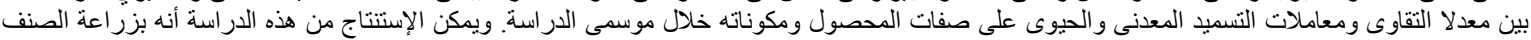

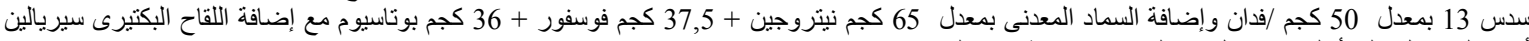

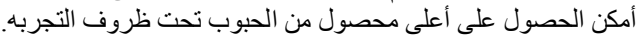

